\title{
Evaluation of canine leishmaniasis and concomitant seropositivity for Babesia canis and rickettsia in a nonendemic area in the central west region of Minas Gerais
}

\author{
Avaliação da leishmaniose canina e soropositividade \\ concomitante com Babesia canis e rickettsias em área não \\ endêmica no Centro Oeste de Minas Gerais.
}

\begin{abstract}
Marcella Oliveira Gama-Melo' (1), Bruna Torres Silvestre ${ }^{2}$ (D) , Julia Angélica Gonçalves da Silveira ${ }^{3}$ (D) Talita Pereira Vaz ${ }^{4}$ (D) , José Ronaldo Barbosa ${ }^{5}$ (D) Múcio Flávio Barbosa Ribeiro ${ }^{3}$ (D) \& Gilberto Fontes ${ }^{6 *}$ (D)

'Pharmaceutical biochemistry, MSc. Programa de pós-graduação em Ciências da Saúde, Universidade Federal de São João delRei - UFSJ, Divinópolis, MG, Brasil

²Biologist, DSc. Laboratório de Protozoologia Veterinária, Departamento de Parasitologia, Instituto de Ciências Biológicas - ICB, Universidade Federal de Minas Gerais - UFMG, Belo Horizonte, MG, Brasil

${ }^{3}$ Veterinarians, DSc. Laboratório de Protozoologia Veterinária, Departamento de Parasitologia, Instituto de Ciências Biológicas - ICB, Universidade Federal de Minas Gerais - UFMG, Belo Horizonte, MG, Brasil

${ }^{4}$ Veterinarian, MSc. Programa de pós-graduação em Ciências da Saúde, Universidade Federal de São João del-Rei - UFSJ, Divinópolis, MG, Brasil

${ }^{5}$ Pharmaceutical biochemistry, MSc. Fundação Ezequiel Dias - FUNED, Belo Horizonte, MG, Brasil

${ }^{6}$ Pharmaceutical biochemistry, DSc. Programa de pós-graduação em Ciências da Saúde, Laboratório de Parasitologia, Universidade Federal de São João del-Rei - UFSJ, Divinópolis, MG, Brasil
\end{abstract}

\begin{abstract}
Among the infections caused by arthropods in dogs are Leishmania infantum, Babesia canis and rickettsias Ehrlichia canis and Anaplasma phagocytophilum. Studies show, in Brazil, high rates of co-infection in dogs by these agents. In Carmo da Mata, Central West of Minas Gerais there are no reports of cases of human or canine visceral leishmaniasis (CVL). In this municipality, the existence and prevalence of LVC and concomitant seropositivity with $B$. canis and rickettsias were evaluated. In the urban area, 433 domiciled dogs were tested for Leishmania infection, with three immunological tests (rapid immunochromatography and ELISA), with a prevalence of 0.7\% (95\% CI: 0.2-1.9). To evaluate the concomitant seropositivity, 433 dogs were evaluated by indirect immunofluorescence reaction, with 166 (38.3\%) reagents for A. phagocytophilum, 171 (39.5\%) for B. canis and 231 (53.3\%) for E. canis. Of the total, 192 (44.2\%) presented concomitant seropositivity with the three agents. Of the three dogs with CVL, one had only CVL and two had concomitant seropositivity, one with B. canis and the third with A. phagocytophilum and E. canis. Immunosuppression caused to dogs by ehrlichiosis can lead to an increase in cases of LVC and thus, it is necessary preventive measures to avoid the expansion of LVC in the municipality.
\end{abstract}

Keywords: canine visceral leishmaniasis, prevalence, concomitant seropositivity, rickettsias, Babesia.

\section{Resumo}

Dentre as infecções causadas por artrópodes em cães destacam-se Leishmania infantum, Babesia canis, Ehrlichia canis e Anaplasma phagocytophilum. Estudos mostram, no Brasil, altas taxas de co-infecção em cães por esses agentes. Em Carmo da Mata, Centro Oeste de Minas Gerais não existe notificações de casos de leishmanioses visceral humana e canina (LVC). Neste município foram avaliadas a existência e prevalência de LVC e soropositividade concomitante com B. canis e rickettsias. Na área urbana foram avaliados 433 cães domiciliados, pelos testes imunológicos (imunocromatografia rápida e ELISA), para verificação da infecção por Leishmania, sendo três reagentes, com prevalência de 0,7\% (IC95\%:0,2-1,9). Para avaliar a soropositividade concomitante, 433 cães foram avaliados por reação de imunofluorescência indireta, sendo 166 (38,3\%) reagentes para A. phagocytophilum, 171 (39,5\%) para B. canis e 231 (53,3\%) para E. canis. Do total, 192 (44,2\%) apresentaram soropositividade concomitante pelos três agentes. Dos três cães com LVC, um tinha apenas LVC e dois apresentaram soropositividade concomitante, um com B. canis e o terceiro com A. phagocytophilum e E. canis. Imunossupressão causada aos cães pela erliquiose pode levar ao aumento de casos de LVC e assim, faz-se necessário a adoção de medidas preventivas para evitar a expansão da LVC no município.

Palavras-chave: leishmaniose visceral canina, prevalência, soropositividade concomitante, rickettsias, Babesia.

\section{BJ M \\ Brazilian Journal of Veterinary Medicine \\ p-ISSN 0100-2430 \\ e-ISSN 2527-2179 \\ ఠ}

How to cite: Gama-Melo, M. O., Silvestre, B. T., Silveira, J. A. G., Vaz, T. P., Barbosa, J. R., Ribeiro, M. F. B., \& Fontes, G. (2019). Evaluation of canine leishmaniasis and concomitant seropositivity for Babesia canis and rickettsia in a nonendemic area in the central west region of Minas Gerais. Brazilian Journal of Veterinary Medicine, 41, e101819. http://dx.doi.org/10.29374/2527-2179.bjvm101819

Financial support: None.

Conflict of interests: No conflict of interests declared concerning the publication of this article.

Received: December 19, 2018.

Accepted: March 19, 2019.

The study was carried out at Laboratório de Parasitologia, Universidade Federal de São João del-Rei - UFSJ, Divinópolis, MG, Brasil.

\section{*Correspondence}

Gilberto Fontes

Universidade Federal de São João del Rei - UFS J Rua Sebastião Gonçalves Coelho, 400, Bairro Chanadour, Campus Centro Oeste CEP 35501-296 - Divinópolis (MG), Brasil E-mail:gfontes@ufsj.edu.br

Copyright Gama-Melo et al. This is an Open Access article distributed under the terms of the Creative Commons Attribution Non-Commercial License which permits unrestricted non-commercial use, distribution, and reproduction in any medium provided the original work is properly cited. 


\section{Introduction}

Leishmaniasis are part of a group of diseases with different clinical and epidemiological characteristics, which are considered neglected by the World Health Organization (World Health Organization, 2018). Visceral leishmaniasis (VL), also known as kala-azar, has viscerotropic characteristics and is considered a systemic zoonosis of chronic evolution, which if untreated, can be fatal (Brasil, 2014a). VL has been reported in five Brazilian regions, and the number of human VL (HVL) cases has increased significantly in Minas Gerais.

The presence of Lutzomyia longipalpis phlebotomine sandflies was detected in the municipality of Carmo da Mata, located in the central west region of Minas Gerais, but there are no reports of HVL cases and no epidemiological studies on canine VL (CVL) (Minas Gerais, 2016). According to the Visceral Leishmaniasis Control Program Manual (PC-VL) of the Brazilian Ministry of Health (MS), these characteristics define the city as a silent and receptive area for VL transmission (Brasil, 2014b).

Dogs are the main reservoir of Leishmania infantum parasites in urban environments, and canine cases of leishmaniasis precede human cases. Control strategies proposed by the MS include canine reservoirs, insecticide application, and diagnosis and early treatment of human cases. These actions should be executed together for better effectiveness (Brasil, 2014b).

Other canine diseases transmitted by arthropods, mainly Rhipicephalus sanguineus ticks, such as canine granulocytic anaplasmosis, babesiosis, and ehrlichiosis, have clinical signs similar to those of CVL (Dumler et al., 2001; Gonçalves et al., 2014). Recent studies have shown the occurrence of coinfection in dogs, with Leishmania and other parasites such as Babesia canis and rickettsia such as Anaplasma phagocytophilum and Ehrlichia canis in several regions of Brazil (Oliveira et al., 2008; Paulan et al., 2013; Gonçalves et al., 2014).

The close interaction between humans and dogs and the susceptibility of both species to vector-borne diseases make it relevant to conduct studies and evaluate the occurrence of these coinfections.

The main objective of the present study was to evaluate the existence and prevalence of CVL dogs seropositive for Babesia canis and rickettsia in the municipality of Carmo da Mata, Minas Gerais.

\section{Material and methods}

The study was approved by the Animal Ethics Committee of the Federal University of São João del Rei (protocol no. 016/2015). This cross-sectional study was conducted in the municipality of Carmo da Mata, Minas Gerais (Figure 1), which has an estimated total population of 10,927 inhabitants (Instituto Brasileiro de Geografia e Estatística, 2010). The study used the stratified sampling method to verify the existence of CVL and concomitant seropositivity for Babesia canis and rickettsia in the urban area of Carmo da Mata, between July and October 2015.

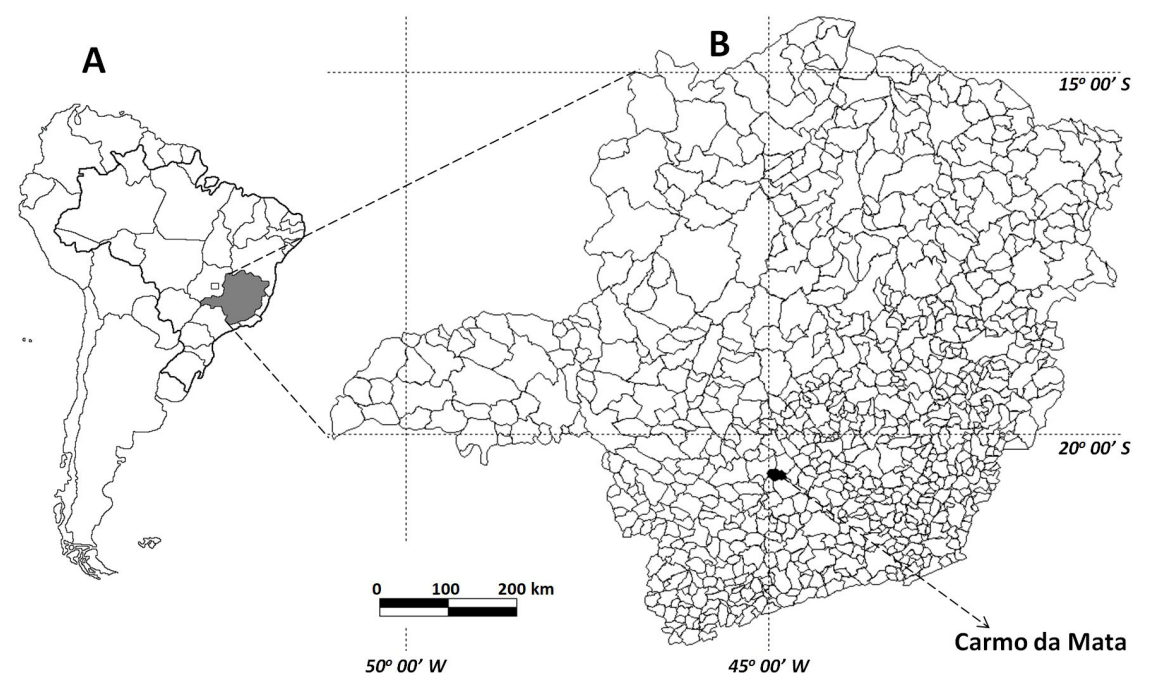

Figure 1. Location map of the municipality of Carmo da Mata, Minas Gerais State, Brazil. A: South America; B: Minas Gerais State. 
The current study utilized the estimate of one dog for every five inhabitants (Brasil, 2014b), with 1,713 dogs estimated for an urban human population of 8,565 inhabitants.

According to the PC-VL of the MS, a canine serological survey should be performed in a municipality with silent VL transmission which has a canine population of more than 500 animals, and no previous studies on the prevalence of CVL (Brasil, 2014b).

The stratified sample of 430 dogs was calculated based on Table 1 of the PC-VL, estimating the canine population at over 1,000 dogs and a mean prevalence rate of 1.1 to $2 \%$ (used when there are no previous data on the existence of this parasitosis in the study area), and taking 5\% as the level of significance (Brasil, 2014b).

Conglomerate sampling was used in the urban area, in which strata are sectors (neighborhoods) and conglomerates are blocks. These blocks were chosen using a random number table. For better spatial distribution of the sample in the strata, 50\% of the households in the blocks were systematically included and canine blood collection started from the northernmost corner (Brasil, 2014b).

The cephalic or jugular vein was used to collect $5 \mathrm{~mL}$ blood samples from the 433 sampled dogs domiciled in the municipal urban area. Serum obtained after centrifugation at $3000 \mathrm{rpm}$ for 10 minutes was frozen and subsequently tested for the evaluated parasites.

According to the MS protocol, only animals that are CVL-positive in the rapid immunochromatographic test (TR-DPP ${ }^{\circledR}$ ) should have a venous blood sample collected for ELISA (confirmatory). Animals that are positive for both diagnostic techniques are considered CVL-positive.

Tabela 1. Distribution of dogs evaluated for canine visceral leishmaniasis, babesiosis, ehrlichiosis, and anaplasmosis (mono-parasitism, concomitant seropositivity and poly-parasitism) in the municipality of Carmo da Mata, Minas Gerais State, Brazil, 2016.

\begin{tabular}{|c|c|c|}
\hline \multirow[b]{2}{*}{ Pathogens } & \multicolumn{2}{|l|}{ Dogs domiciled } \\
\hline & Dogs with mono-parasitism & $\begin{array}{l}\text { Frequency } \\
(n=433)\end{array}$ \\
\hline Babesia canis & $33 / 433$ & $7.6 \%$ \\
\hline Anaplasma phagocytophilum & $24 / 433$ & $5.5 \%$ \\
\hline Ehrlichia canis & $60 / 433$ & $13.9 \%$ \\
\hline TOTAL & $117 / 433$ & $27 \%$ \\
\hline Concomitant seropositivity & Dogs with concomitant seropositivity & $\begin{array}{l}\text { Frequency } \\
(n=433)\end{array}$ \\
\hline Babesia canis + Anaplasma phagocytophilum & $21 / 433$ & $4.8 \%$ \\
\hline Anaplasma phagocytophilum + Ehrlichia canis & $55 / 433$ & $12.7 \%$ \\
\hline Babesia canis + Ehrlichia canis & $50 / 433$ & $11.5 \%$ \\
\hline $\begin{array}{l}\text { Babesia canis + Anaplasma phagocytophilum + } \\
\text { Ehrlichia canis }\end{array}$ & $66 / 433$ & $15.2 \%$ \\
\hline TOTAL & $192 / 433$ & $44.2 \%$ \\
\hline $\begin{array}{l}\text { Concomitant seropositivity with } \\
\text { Leishmania }\end{array}$ & Dogs with concomitant seropositivity & $\begin{array}{l}\text { Frequency } \\
(n=433)\end{array}$ \\
\hline Leishmania + Babesia canis & $1 / 433$ & $0.2 \%$ \\
\hline $\begin{array}{l}\text { Leishmania + Anaplasma phagocytophilum + } \\
\text { Ehrlichia canis }\end{array}$ & $1 / 433$ & $0.2 \%$ \\
\hline Pathogens & Dogs with poly-parasitism & $\begin{array}{l}\text { Frequency } \\
(n=433)\end{array}$ \\
\hline Leishmania & $3 / 433$ & $0.7 \%$ \\
\hline Babesia canis & $171 / 433$ & $39.5 \%$ \\
\hline Anaplasma phagocytophilum & $166 / 433$ & $38.3 \%$ \\
\hline Ehrlichia canis & $231 / 433$ & $53.3 \%$ \\
\hline
\end{tabular}


In this study, all sampled animals underwent the two immunological tests for CVL diagnosis (TR-DPP ${ }^{\circledR}$ and ELISA). The existence of concomitant seropositivity was analyzed through indirect immunofluorescence reactions (IIFRs) for anti-Babesia, anti-Anaplasma, and anti-Ehrlichia antibodies.

The TR-DPP ${ }^{\circledR}$ and ELISA tests were performed using kits produced by Biomanguinhos/FIOCRUZ and following the manufacturer's recommendations. The tests were conducted at the Parasitology Laboratory of the Federal University of São João del Rei - Central-West Campus, which is accredited by the Ezequiel Dias Foundation as a regional reference center for CVL diagnosis. The IIFRs to diagnose babesiosis, anaplasmosis, and ehrlichiosis were conducted at the Veterinary Protozoology Laboratory of the Department of Parasitology of the Biological Sciences Institute (ICB) of the Federal University of Minas Gerais (UFMG).

E. canis and A. phagocytophilum antigens were obtained from infected IDE8 cells, using the method previously described by Aguiar et al. (2007). Babesia antigens were obtained from canine blood smears containing $B$. vogeli parasitized erythrocytes, prepared according to the Instituto Interamericano de Cooperación para la Agricultura (1987). For antibody screening, the slides were examined on an Olympus ${ }^{\circledR}$ BX41 epifluorescence microscope (Olympus Corporation, Tokyo, Japan) under 20X and 40X magnification. Fluorescent serological samples were diluted to 1:40.

\section{Results}

\section{Urban dog samples}

Of the 433 domiciled dogs sampled and serologically and clinically evaluated, 227 were female (52.4\%) and 206 were male (47.6\%); 64.9\% were mongrels. Most dogs were in the age group of 6 months to 5 years (64.9\%), followed by $5-10$ years $(27.9 \%)$ and $>10$ years $(7.2 \%)$.

A total of 371 dogs (85.7\%) had no clinical signs suggestive of parasitic infection by Leishmania. Of the 62 remaining animals (14.3\%) that presented some clinical signs, two presented all signs evaluated (adenopathy, alopecia, keratoconjunctivitis and/or blindness, dermatitis, foot edema, weight loss, onychogryphosis, and ulcers), nine presented two clinical signs concomitantly, four presented three concomitant signs, and 48 (11.1\%) presented only one sign evaluated.

\section{CVL diagnosis by TR-DPP ${ }^{\circledR}$ and ELISA}

Of the 433 domiciled dogs evaluated in the urban area, 10 (2.3\%) were positive in the TR-DPP ${ }^{\circledR}$ and, of these, three (0.7\%) were positive in the ELISA. According to the PC-VL recommendations, only the dogs considered positive in the TR-DPP ${ }^{\circledR}$ and ELISA were considered positive for CVL. Therefore, the CVL prevalence for the domiciled dogs sampled in the urban area of Carmo da Mata was 0.7\% (95\%CI: 0.2-1.9).

\section{Concomitant canine seropositivity for $B$. canis and rickettsia in urban areas}

The 433 domiciled dogs were also investigated for B. canis, A. phagocytophilum, and E. canis using IIFRs. Of these, 124 animals (28.6\%) were not positive for any of these pathogens, and 117 (27\%) were positive for only one pathogen: 33 (7.6\%) for B. canis, 24 (5.5\%) for A. phagocytophilum, and 60 (13.9\%) for E. canis (Table 1).

The remaining 192 dogs were concomitantly seropositive for at least two of the evaluated pathogens. Table 1 shows the parasitic associations found for these 192 dogs for B. canis, A. phagocytophilum, and E. canis. Of these, 66 (15.2\%) presented the parasitic association of B. canis + A. phagocytophilum + E. canis, $55(12.7 \%)$ presented with A. phagocytophilum + E. canis, $50(11.5 \%)$ with B. canis + E. canis, and 21 (4.8\%) presented the parasitic association B. canis + A. phagocytophilum (Table 1).

Of the three CVL dogs, one presented only CVL and two presented concomitant seropositivity, one for Leishmania and B. canis and the other for Leishmania, A. phagocytophilum, and E. canis (Table 1).

Of the 433 dogs evaluated, 231 mono- and poly-parasitized dogs (53.3\%) were positive for E. canis, 171 (39.5\%) for B. canis, and 166 (38.3\%) for A. phagocytophilum (Table 1). 


\section{Discussion}

Dogs are important links in the transmission of the VL etiological agent and some studies have been conducted in the central west region of the state of Minas Gerais in order to better explain parasite dispersion in this region (Silva et al., 2008; Teixeira-Neto et al., 2014; Menezes et al., 2015; Faria et al., 2017).

A comparison of previous studies showed a significant difference between CVL prevalence rates in the municipalities of Divinópolis (4.6\%) (Teixeira-Neto et al., 2014) and Carmo da Mata (0.7\%), with a prevalence ratio of 6.7 (95\% CI: 2.1-20.8). A significant difference was found between the municipalities of Iguatama (8.3\%) (Faria et al., 2017) and Carmo da Mata (0.7\%), with a prevalence ratio of 12 (95\% CI: 3.7-38.7). There was also a significant difference of CVL prevalence between the municipalities of Bom Sucesso (3\%) (Silva et al., 2008) and Carmo da Mata (0.7\%), with a prevalence ratio of 4.3 (95\% CI: 1.3-14.4).

There were no significant CVL differences in Carmo da Mata for sex and age of the animals, similar to the studies conducted in the western region of the state of Minas Gerais (Almeida et al., 2009; Santis et al., 2013; Faria et al., 2017). Clinical signs seen in CVL dogs in Carmo da Mata were similar to clinical signs observed in other studies and included skin changes, onychogryphosis, and weight loss (Almeida et al., 2012; Barata et al., 2013; Faria et al., 2017).

Some researchers stated that the serological tests used to diagnose CVL could present cross-reactivity with other parasites and rickettsia (Mancianti et al., 1996; Gomes \& Cordeiro, 2004; Ferreira et al., 2007; Silva et al., 2011). However, Oliveira et al. (2008) rejected the hypothesis of cross-reaction among B. canis, E. canis, and Leishmania agents; they believe there are coinfections among these agents, especially in endemic regions. Due to biological differences, taxonomic classifications, and phylogenetic differences between rickettsia and protozoa, the hypothesis of coinfection is more acceptable than the occurrence of serological cross-reaction in the diagnosis of these infections (Dumler et al., 2001; Almosny et al., 2002; Krawczak et al., 2015.)

Coinfection is a rarely studied phenomenon and most studies evaluate infections caused by only one agent (Sousa et al., 2013; Falcão et al., 2014). Most studies on the evaluation of multiple-agent infections in dogs are based on clinical reports (Gal et al., 2007; Sasanelli et al., 2009; Gonçalves et al., 2014; Silveira et al., 2015) which highlight severe clinical changes, difficult diagnosis, compromised treatment, and unfavorable prognosis (Vargas-Hernández et al., 2012).

In this study, the analyzed animals were evaluated for some agents transmitted by ticks to dogs and possibly to humans. Although tick infestation was not evaluated during collection, it was possible to see that some animals were infested with significant numbers of ticks. The large number of dogs concomitantly seropositive for tick-borne agents leads us to believe that the evaluated animals were infested with these arthropods. R. sanguineus ticks are frequently found in urban areas (Labruna \& Pereira, 2001), besides being a species commonly found on dogs in Brazil (Oliveira et al., 2008; Morais et al., 2013).

It is hypothesized that $R$. sanguineus can act as mechanical CVL vectors because CVL and HVL have already been reported in areas free of phlebotomine sandflies (Michalsky et al., 2009). Moreover, L. infantum DNA was detected in ticks through PCR (Coutinho et al., 2005; Dantas-Torres, 2011; Colombo et al., 2011; Morais et al., 2013; Campos \& Costa, 2014). However, a study by Paz et al. (2010) concluded that parasite maintenance and multiplication of Leishmania was unlikely in ticks. A recent study detected promastigote forms in the intestines, ovaries, and salivary glands of ticks, emphasizing the need for more studies on the role of ticks in CVL transmission in Brazil (Viol et al., 2016).

Tick-infested dogs present a 53\% higher chance of being infected by L. infantum compared to non-infested dogs (Paz et al., 2010) because tick infestation causes anemia and weakness, increasing the chance of coinfection (Sousa et al., 2013).

The prevalence of B. canis in dogs from Carmo da Mata was significantly lower than its reported prevalence in other studies conducted in Brazil. Ribeiro et al. (1990) reported that the prevalence of dogs infected with B. canis was $66.9 \%$ in Belo Horizonte. Studies conducted in Campo Grande (Mato Grosso do Sul) showed a prevalence of 81.6\% (Sousa et al., 2013), and in Ilha Solteira (São Paulo), 72\% (Paulan et al., 2013). In Petrolina (Pernambuco), the prevalence was 57.9\% (Araújo et al., 2015) and in Jaboticabal (São Paulo), it was 67\% (Oliveira et al., 2008). 
There was no significant difference between the prevalence of B. canis in dogs in Carmo da Mata and the prevalence reported in other studies, such as a study in the city of São Paulo, where the prevalence was 42.4\% (Dell'Porto et al., 1993).

The prevalence of canine E. canis rickettsia in Carmo da Mata was significantly higher when compared to prevalence rates reported in studies conducted in other Brazilian municipalities, such as 37.9\% in Monte Negro, Rondônia (Aguiar et al., 2007); 36\% in the microregion of llhéus and Itabuna, in Bahia (Carlos et al., 2007); and 42.5\% in Cuiabá, in Mato Grosso (Silva et al., 2010). There was no significant difference between the prevalence found in Carmo da Mata and Belo Horizonte (Oliveira et al., 2008).

E. canis prevalence rates higher than those observed in Carmo da Mata have also been reported. Some studies in São Paulo showed E. canis infection prevalence of $75.3 \%$ in Ilha Solteira (Paulan et al., 2013), 78\% in Jaboticabal (Oliveira et al., 2008), and 66.5\% in Presidente Prudente (D'Andrea et al., 2015). These studies report a significant difference when compared to the prevalence noted in Carmo da Mata.

There are few studies on A. phagocytophilum infection in Brazil (Silveira et al., 2015). A study conducted by Santos et al. (2013) in Rio de Janeiro using qPCR showed that $6 \%$ of the dogs were infected. A study on E. canis and A. phagocytophilum coinfection in dogs conducted in Belo Horizonte showed dogs infected by A. phagocytophilum for the first time in Brazil using parasitic and molecular diagnostic methods (Silveira et al., 2015). This parasitosis should be further studied, since dogs act as sentinels for human exposure, posing as an infection source for ticks that can transmit the agent to humans (Falcão et al., 2014).

In the present study, the prevalence of A. phagocytophilum was 5.5\% for mono-parasitized dogs and 38.3\% for mono- and poly-parasitized dogs. None of the published studies on this subject used a random sample with more dogs evaluated than the present study. The prevalence of 38.3\% found in this study is significantly different when compared to the rate found in a study conducted in southern Germany with Bernese Mountain Dogs, with a relative risk of 1.3 (95\%CI: 1.1-1.6) (Preyß-Jägeler et al., 2016). A study conducted in Brazil reported a 35\% occurrence of canine A. phagocytophilum in Campos dos Goytacazes, in the state of Rio de Janeiro (Falcão et al., 2014).

It is important to consider the hypothesis that the presence of one agent can act as a facilitator for the onset of other infections, which can be aggravated (Sousa et al., 2013). The high prevalence of $E$. canis is can result in immunosuppression (Boozer \& MacIntire, 2003), as observed in this study, wherein the coinfections with higher prevalence were those involving E. canis infection.

The CVL and canine ehrlichiosis epidemiologic studies overlap in many areas of the world, which is justified by similar activity periods of agent vectors (Mekuzas et al., 2009). This indicates the importance of dog surveillance in the municipality of Carmo da Mata, since E. canis infection can contribute to an increased prevalence of CVL (Mekuzas et al., 2009). In addition, Carmo da Mata has some risk factors, such as the presence of L. longipalpis vector, CVL positive dogs, and proximity to other areas where there is a well-established transmission cycle, including HVL cases.

\section{Conclusions}

The low prevalence of CVL in Carmo da Mata indicates a possible expansion of this parasitosis in the central west region of Minas Gerais, which is considered safe by the Ministry of Health and Minas Gerais State Health Department.

Preventive measures including control of tick infestations in dogs are necessary in order to avoid a possible increase in the number of cases of tick-borne infection. Tick control will also decrease the occurrence of human infections caused by A. phagocytophilum, since dogs act as sentinels for the transmission of this disease to humans.

Even with the low prevalence found in this study, CVL should be controlled because of the high rate of $E$. canis positivity in dogs; the immunosuppression caused by ehrlichiosis can lead to an increase in the number of CVL cases.

We suggest that veterinarians should consider the differential diagnosis for the evaluated agents, since the occurrence of concomitant seropositivity may lead to high parasite rates and to the permanence of enzootic diseases in the municipality. 


\section{Acknowledgements}

We thank the City Hall of Carmo da Mata, Minas Gerais, for providing the support and logistics required for the accomplishment of field work; Gabriela Oliveira; veterinarians Antônia Magalhães and Cristiano Beirigo for their collaboration with field and laboratory work. Tony Hiroshi Katsuragawa for the map.

\section{References}

Aguiar, D. M., Saito, T. B., Hagiwara, M. K., Machado, R. Z., \& Labruna, M. B. (2007). Diagnóstico sorológico de erliquiose canina com antígeno brasileiro de Ehrlichia canis. Revista Científica Rural, 37(3), 796-802. http:// dx.doi.org/10.1590/S0103-84782007000300030.

Almeida, A. B. P. F., Faria, R. P., Pimentel, M. F. A., Dahroug, M. A. A., Turbino, N. C. M. R., \& Sousa, V. R. F. (2009). Inquérito soroepidemiológico de leishmaniose canina em áreas endêmicas de Cuiabá, Estado de Mato Grosso. Revista da Sociedade Brasileira de Medicina Tropical, 42(2), 156-159. http://dx.doi.org/10.1590/S003786822009000200012. PMid:19448933.

Almeida, A. B. P. F., Sousa, V. R. F., Cruz, F. A. C. S., Dahroug, M. A. A., Figueiredo, F. B. F., \& Madeira, M. F. (2012). Canine visceral leishmaniasis: seroprevalence and risk factors in Cuiabá, Mato Grosso, Brazil. Revista Brasileira de Parasitologia Veterinária, 21(4), 359-365. http://dx.doi.org/10.1590/S1984-29612012005000005. PMid:23184322.

Almosny, N. R. P., Massard, C. L., Labarthe, N. V., O’Dwyer, L. H., Souza, A. M. D. E., \& Alves, L. C. (2002). Erliquiose em pequenos animais domésticos e como zoonose. In N. R. R. Almosny \& C. L. Massard (Eds.), Hemoparasitoses em pequenos animais domésticos e como zoonoses (1a ed., pp. 13-56). Rio de Janeiro: LF Livros.

Araújo, A. C., Silveira, J. A. G., Azevedo, S. S., Nieri-Bastos, F. A., Ribeiro, M. F. B., Labruna, M. B., \& Horta, M. C. (2015). Babesia canis vogeli infection in dogs and ticks in the semiarid region of Pernambuco, Brazil. Pesquisa Veterinária Brasileira, 35(5), 456-461. http://dx.doi.org/10.1590/S0100-736X2015000500012.

Barata, R. A., Peixoto, J. C., Tanure, A., Gomes, M. E., Apolinário, E. C., Bodevan, E. C., Araújo, H. S., Dias, E. S., \& Pinheiro, A. C. (2013). Epidemiology of visceral Leishmaniasis in a reemerging focus of intense transmission in Minas Gerais state, Brazil. BioMed Research International,2013, 405083. http://dx.doi.org/10.1155/2013/405083. PMid:24000322.

Boozer, A. L., \& MacIntire, D. K. (2003). Canine babesiosis. The Veterinary Clinics of North America. Small Animal Practice, 33(4), 885-904. http://dx.doi.org/10.1016/S0195-5616(03)00039-1. PMid:12910748.

Brasil, Ministério da Saúde. (2014a). Vigilância de A a Z: Leishmaniose Visceral. Retrieved in 2018, September 25, from http://portalsaude.saude.gov.br/index.php/o-ministerio/principal/leia-mais-o-ministerio/726-secretaria-svs/ vigilancia-de-a-a-z/leishmaniose-visceral-lv/11330-descricao-da-doenca

Brasil, Ministério da Saúde. (2014b). Manual de vigilância e controle da Leishmaniose Visceral. Retrieved in 2018, July 25, from http://bvsms.saude.gov.br/bvs/publicacoes/manual_vigilancia_controle_leishmaniose_ visceral_ledicao.pdf

Campos, J. H. F., \& Costa, F. A. L. (2014). Participation of ticks in the infectious cycle of canine visceral leishmaniasis, in Teresina, Piauí, Brazil. Revista do Instituto Brasileiro de Medicina Tropical, 56(4), 297-300. http://dx.doi. org/10.1590/S0036-46652014000400005. PMid:25076429.

Carlos, R. S. A., Muniz Neta, E. S., Spagnol, F. H., Oliveira, L. L. S., Brito, R. L. L., Albuquerque, G. R., \& Almosny, N. R. P. (2007). Frequência de anticorpos anti-Erblichia canis, Borrelia burgdorferi e antígenos de Dirofilaria immitis em cães na microrregião Ilhéus-Itabuna, Bahia, Brasil. Revista Brasileira de Parasitologia Veterinária, 16(3), 117-120. http://dx.doi.org/10.1590/S1984-29612007000300001. PMid:18078596.

Colombo, F. A., Odorizzi, R. M. F. N., Laurenti, M. D., Galati, E. A. B., Canavez, F., \& Pereira-Chioccola, V. L. (2011). Detection of Leishmania (Leishmania) infantum RNA in fleas and ticks collected from naturally infected dogs. Parasitology Research, 109(2), 267-274. http://dx.doi.org/10.1007/s00436-010-2247-6. PMid:21221638.

Coutinho, M. T., Bueno, L. L., Sterzik, A., Fujiwara, R. T., Botelho, J. R., De Maria, M., Genaro, O., \& Linardi, P. M. (2005). Participation of Rhipicephalus sanguineus (Acari: Ixodidae) in the epidemiology of canine visceral leishmaniasis. Veterinary Parasitology, 128(1-2), 149-155. http://dx.doi.org/10.1016/j.vetpar.2004.11.011. PMid:15725545.

D’Andrea, L. A. Z., Fonseca, E. S., Prestes-Carneiro, L. E., Guimarães, R. B., Yamashita, R. C., Soares, C. N., Hiramoto, R. M., \& Tolezano, J. E. (2015). The shadows of a ghost: a survey of canine leishmaniasis in Presidente Prudente and its spatial dispersion in the western region of São Paulo state, an emerging focus of visceral leishmaniasis in Brazil. Veterinary Research, 11, 273-280. PMid:26503368.

Dantas-Torres, F. (2011). Ticks as vectors of Leishmania parasites. Trends in Parasitology, 27(4), 155-159. http:// dx.doi.org/10.1016/j.pt.2010.12.006. PMid:21227752.

Dell'Porto, A., Oliveira, M. R., \& Miguel, O. (1993). Babesia canis in stray dogs from the city of São Paulo: Comparative studies between the clinical and hematological aspects and the indirect fluorescence antibody test. Revista Brasileira de Parasitologia Veterinária, 2, 37-40. 
Dumler, J. S., Barbet, A. F., Bekker, C. P. J., Dasch, G. A., Palmer, G. H., Ray, S. C., Rikihisa, Y., \& Rurangirwa, F. R. (2001). Reorganization of genera in the families Rickettsiaceae and Anaplasmaceae in the order Rickettsiales: unification of some species of Ehrlichia with Anaplasma, Cowdria with Ehrlichia and Ehrlichia with Neorickettsia, descriptions of six new species combinations and designation of Ehrlichia equi and HGE agent as subjective synonyms of Ehrlichia phagocytophila. International Journal of Systematic and Evolutionary Microbiology, 51(Pt 6), 2145-2165. http://dx.doi.org/10.1099/00207713-51-6-2145. PMid:11760958.

Falcão, B. A., Pinto, A. B. T., Jardim, M. P. B., \& Albernaz, A. P. (2014). Ocorrência de reagentes positivos para agentes da Anaplasmose Granulocítica por testes imunoenzimáticos de animais sentinelas em Campos dos Goytacazes, Rio de Janeiro. Revista Científica da Faculdade de Medicina de Campos, 9, 35-41. Retrieved in 2018, July 25, from https://www.fmc.br/revista/V9N2P35-41.pdf

Faria, M. T., Barbosa, F. S., Teixeira-Neto, R. G., Pinheiro, G. R. G., Manhani, M. N., Marcelino, A. P., Barbosa, J. R., \& Fontes, G. (2017). Autochthonous case of canine visceral Leishmaniasis in a non-endemic area in Minas Gerais, Brazil. Pesquisa Veterinária Brasileira, 37(12), 1505-1508. http://dx.doi.org/10.1590/s0100-736x2017001200023.

Ferreira, E. C., Lana, M., Carneiro, M., Reis, A. B., Paes, D. V., Silva, E. S., Schallig, H., \& Gontijo, C. M. (2007). Comparison of serological assays for the diagnosis of canine visceral leishmaniasis in animals presenting different clinical manifestations. Veterinary Parasitology, 146(3-4), 235-241. http://dx.doi.org/10.1016/j. vetpar.2007.02.015. PMid:17403582.

Gal, A., Harrus, S., Arcoh, I., Lavy, E., Aizenberg, I., Mekuzasyisaschar, Y., \& Baneth, G. (2007). Coinfection with multiple tick-borne and intestinal parasites in a 6-week-old dog. The Canadian Veterinary Journal. La Revue Veterinaire Canadienne, 48(6), 619-622. PMid:17616060.

Gomes, A. P. S., \& Cordeiro, R. L. R. (2004). Reação cruzada no diagnóstico sorológico de leishmaniose canina. Revista Brasileira de Parasitologia Veterinária, 23, 235-238.

Gonçalves, L. R., Filgueira, K. D., Ahid, S. M. M., Pereira, J. S., Vale, A. M., Machado, R. Z., \& André, M. R. (2014). Study on coinfecting vector-borne pathogens in dogs and ticks in Rio Grande do Norte, Brazil. Revista Brasileira de Parasitologia Veterinária, 23(3), 407-412. http://dx.doi.org/10.1590/S1984-29612014071. PMid:25271465.

Instituto Brasileiro de Geografia e Estatística. (2010). Cidades: Carmo da Mata. Rio de Janeiro: IBGE. Retrieved in 2018, October 24, from http://cod.ibge.gov.br/2390N

Instituto Interamericano de Cooperación para la Agricultura. (1987). Técnicas para el diagnóstico de babesioses y anaplasmosis bovina. San José: IICA.

Krawczak, F. S., Reis, I. A., Silveira, J. A., Avelar, D. M., Marcelino, A. P., Werneck, G. L., Labruna, M. B., \& Paz, G. F. (2015). Leishmania, Babesia and Ehrlichia in urban pet dogs: co-infection or cross-reaction in serological methods? Revista da Sociedade Brasileira de Medicina Tropical, 48(1), 64-68. http://dx.doi.org/10.1590/00378682-0291-2014. PMid:25860466.

Labruna, M. B., \& Pereira, M. C. (2001). Carrapatos em cães no Brasil. Clínica Veterinária, 30, 24-32.

Mancianti, F., Pedonese, F., \& Poli, A. (1996). Evaluation of dot enzyme-linked immunosorbent assay (dot-ELISA) for the serodiagnosis of canine leishmaniasis as compared whit indirect immunofluorescent assay. Veterinary Parasitology, 65(1-2), 1-9. http://dx.doi.org/10.1016/0304-4017(96)00946-6. PMid:8916395.

Mekuzas, Y., Gradoni, L., Oliva, G., Foglia Manzillo, V., \& Baneth, G. (2009). Ehrlichia canis and Leishmania infantum co-infection: a 3-year longitudinal study in naturally exposed dogs. European Society of Clinical Microbiology and Infectious Diseases, 15(Suppl 2), 30-31. PMid:19416288.

Menezes, J. A., Ferreira, E. C., Andrade-Filho, J. D., Sousa, A. M., Morais, M. H. G., Rocha, A. M. S., Machado-Coelho, G. L. L., Lima, F. P., Madureira, A. P., Garcia, T. C., Freitas, C. R., Soares, R. P., \& Margonari, C. (2015). An integrated approach using spatial analysis to study the risk factors for leishmaniasis in area of recent transmission. BioMed Research International, 2015, 621854. http://dx.doi.org/10.1155/2015/621854. PMid:26229961.

Michalsky, E. M., França-Silva, J. C., Barata, R. A., Lara, E., Silva, F. O., Loureiro, A. M., Fortes-Dias, C. L., \& Dias, E. S. (2009). Phlebotominae distribution in Janaúba, in an area of trasmission for visceral leishmaniasis in Brazil. Memorias do Instituto Oswaldo Cruz, 104(1), 56-61. http://dx.doi.org/10.1590/50074-02762009000100009. PMid:19274377.

Minas Gerais, Secretaria de Estado de Saúde. (2016). Nota Técnica no 030/2016 de 04 de julbo de 2016: situação epidemiológica da Leishmaniose Visceral da URS - Divinópolis, Minas Gerais. Belo Horizonte: SES/MG.

Morais, R. C., Gonçalves, S. C., Costa, P. L., Silva, K. G., Silva, F. J., Silva, R. P., Brito, M. E., Brandão-Filho, S. P., DantasTorres, F., \& Paiva-Cavalcanti, M. (2013). Detection of Leishmania infantum in animals and their ectoparasites by conventional PCR and real time PCR. Experimental \& Applied Acarology, 59(4), 473-481. http://dx.doi. org/10.1007/s10493-012-9611-4. PMid:23132326.

Oliveira, T. M., Furuta, P. I., Carvalho, D., \& Machado, R. Z. (2008). A study of cross-reactivity in serum samples from dogs positive for Leishmania sp., Babesia canis and Ehrlichia canis in enzyme-linked immunosorbent assay and indirect fluorescent antibody test. Revista Brasileira de Parasitologia Veterinária, 17(1), 7-11. http:// dx.doi.org/10.1590/S1984-29612008000100002. PMid:18554433.

Paulan, S. C., Lins, A. G. S., Tenório, M. S., Silva, D. T., Pena, H. F. J., Machado, R. Z., Gennari, S. M., \& Buzetti, W. A. S. (2013). Seroprevalence rates of antibodies against Leishmania infantum and other protozoan and rickettsial parasites in dogs. Revista Brasileira de Parasitologia Veterinária, 22(1), 162-166. http://dx.doi.org/10.1590/S198429612013000100031. PMid:24252965. 
Paz, G. F., Ribeiro, M. F. B., Magalhães, D. F., Sathler, K. P. B., Morais, M. H. F., Fiúza, V. O. P., Brandão, S. T., Werneck, G. L., Fortes-Dias, C. L., \& Dias, E. S. (2010). Association between the prevalence of infestation by Rhipicephalus sanguineus and Ctenocephalides felisfelis and the presence of anti-Leishmania antibodies: a case-control study in dogs from a Brazilian endemic area. Preventive Veterinary Medicine, 97(2), 131-133. http://dx.doi.org/10.1016/j. prevetmed.2010.08.006. PMid:20869131.

Preyß-Jägeler, C., Müller, E., Straubinger, R. K., \& Hartmann, K. (2016). Prevalence of antibodies against Borrelia burgdorferi, Anaplasma phagocytophilum, and Leptospira interrogans serovars in Bernese Mountain Dogs. Tierärztliche Praxis Kleintiere, 44(2), 77-85. PMid:27004451.

Ribeiro, M. F. B., Lima, J. D., Passos, L. M. F., \& Guimarães, A. M. (1990). Frequência de anticorpos fluorescentes anti-Babesia canis em cães de Belo Horizonte, Minas Gerais. Arquivo Brasileiro de Medicina Veterinária e Zootecnia, 42, 511-517.

Santis, B., Santos, E. G. B., Souza, C. S. F., \& Chaves, S. A. M. (2013). Performance of DPP ${ }^{\mathrm{rm}}$ immunochromathographic rapid test (IRT) for canine visceral leishmaniasis: comparison with other serological methods in suspected dogs from Cuiabá, Mato Grosso State, Brazil. Brazilian Journal of Veterinary Research and Animal Science, 50, 198. Retrieved in 2018, July 25, from https://pdfs.semanticscholar.org/a856/d6991ad28c85fc452e132c38c71d3aff1d64. pdf

Santos, H. A., Thomé, S. M. G., Baldani, C. D., Silva, C. B., Peixoto, M. P., Pires, M. S., Vitari, G. L. V., Costa, R. L., Santos, T. M., Angelo, I. C., Santos, L. A., Faccini, J. L. H., \& Massard, C. L. (2013). Molecular epidemiology of the emerging zoonosis agente Anaplasma phagocytophilum (Foggie,1949) in dogs and ixodid ticks in Brazil. Parasites \& Vectors, 6(1), 348. http://dx.doi.org/10.1186/1756-3305-6-348. PMid:24330631.

Sasanelli, M., Paradies, P., Lubas, G., Otranto, D., \& De Caprariis, D. (2009). Atypical clinical presentation of coinfection with Ehrlichia, Babesia and Hepatozoon species in a dog. The Veterinary Record, 164(1), $22-23$. http://dx.doi.org/10.1136/vr.164.1.22. PMid:19122221.

Silva, D. A., Madeira, M. F., Teixeira, A. C., Souza, C. M., \& Figueiredo, F. B. (2011). Laboratory tests performed on Leishmania seroreactive dogs euthanized by the leishmaniasis control program. Veterinary Parasitology, 179(1-3), 257-261. http://dx.doi.org/10.1016/j.vetpar.2011.01.048. PMid:21349644.

Silva, J. N., Almeida, A. B. P. F., Boa Sorte, E. C., Freitas, A. G., Santos, L. G. F., Aguiar, D. M., \& Sousa, V. R. F. (2010). Soroprevalência de anticorpos anti-Ehrlichia canis em cães de Cuiabá, Mato Grosso. Revista Brasileira de Parasitologia Veterinária,19(2), 108-111. http://dx.doi.org/10.1590/S1984-29612010000200008. PMid:20624348.

Silva, M. R., Marques, M. J., Romanha, A. J., Santa Rosa, I. C. A., Carneiro, C. M., \& Reis, A. B. (2008). Autochthonous canine visceral leishmaniasis in a non endemic area: Bom Sucesso, Minas Gerais State, Brazil. Cadernos de Saude Publica, 24(2), 281-286. http://dx.doi.org/10.1590/S0102-311X2008000200006. PMid:18278274.

Silveira, J. A. G., Valente, P. C. L. G., Paes, P. R. O., Vasconcelos, A. V., Silvestre, B. T., \& Ribeiro, M. F. B. (2015). The first clinical and laboratory evidence of co-infection by Anaplasma phagocytophilum and Ehrlichia canis in a Brazilian dog. Ticks and Tick-Borne Diseases, 6(3), 242-245. http://dx.doi.org/10.1016/j.ttbdis.2015.01.003. PMid:25661650.

Sousa, K. C. M., André, M. R., Herrera, H. M., Andrade, G. B., Jusi, M. M. G., Santos, L. L., Barreto, W. T. G., Machado, R. Z., \& Oliveira, G. P. (2013). Detecção sorológica e molecular de patógenos transmitidos por carrapatos em cães de uma área endêmica para Leishmania infantum do estado do Mato Grosso do Sul. Revista Brasileira de Parasitologia Veterinária, 22(4), 525-531. http://dx.doi.org/10.1590/S1984-29612013000400012. PMid:24473877.

Teixeira-Neto, R. G., Silva, E. S., Nascimento, R. A., Belo, V. S., Oliveira, C. L., Pinheiro, L. C., \& Gontijo, C. M. F. (2014). Canine visceral leishmaniasis in an urban setting of Southeastern Brazil: an ecological study involving spatial analysis. Parasites \& Vectors, 7(1), 485. http://dx.doi.org/10.1186/s13071-014-0485-7. PMid:25326767.

Vargas-Hernández, G., André, M. R., Faria, J. L., Munhoz, T. D., Hernandez-Rodriguez, M., Machado, R. Z., \& TinucciCosta, M. (2012). Molecular and serological detection of Ehrlichia canis and Babesia vogeli in dogs in Colombia. Veterinary Parasitology, 186(3-4), 254-260. http://dx.doi.org/10.1016/j.vetpar.2011.11.011. PMid:22130333.

Viol, M. A., Guerrero, F. D., Oliveira, B. C. M., Aquino, M. C. C., Loiola, S. H., Melo, G. D., Gomes, A. H. S., Kanamura, C. T., Garcia, M. V., Andreotti, R., Lima, V. M. F., \& Bresciani, K. D. (2016). Identification of Leishmania spp. Promastigotes in the intestines, ovaries, and salivary glands of Rhipicephalus sanguineus actively infesting dogs. Parasitology Research, 115(9), 3479-3484. http://dx.doi.org/10.1007/s00436-016-5111-5. PMid:27169724.

World Health Organization. (2018). Leishmaniasis: situation and trends. Genebra: WHO. Retrieved in 2018, September 10, from http://www.who. int/leishmaniasis/en// 